\title{
A Panoply of Information for the Practice of Family Medicine
}

\author{
Marjorie A. Bowman, MD, MPA, and Anne Victoria Neale, PhD, MPH
}

The majority of articles in this issue report on clinical conditions, adding to our knowledge base with which we practice family medicine. Topics range from childhood obesity to tobacco abuse treatment for patients with psychiatric disorders. We also have clinical papers on testing for group A streptococcus pharyngitis, incidentalomas identified in chest computed tomography exams, and a case of migraines associated with an ovarian teratoma. Others include long-term use of opioids (with information that could be surprising), and hand washing and face touching in the office. Enjoy the panoply of clinical information! We also have useful information on implementing medication reconciliation, 3 articles that relate to the integration of behavioral health into family medicine, and another 2 articles about recertification. (J Am Board Fam Med 2014;27:303-305.)

\section{Research on Clinical Conditions}

Once again we see many incidental findings on radiologic studies ordered for unrelated reasons. One difference is that the report in this issue by Espinoza et $\mathrm{al}^{1}$ is from a family physician practicebased research network. One-third of the patients who had coronary and abdominal computed tomography scans for the purpose of the research had significant findings (the majority were benign). Of 571 participants, 4 had positive findings that led to significant interventions: 2 underwent coronary surgery, and at least one life may have been saved when the patient's leukemia was found and treated. The balance between testing and incidentalomas continues to be a struggle for physicians and patients.

Using an intensive multidisciplinary treatment program emphasizing the entire family, Endevelt et $\mathrm{al}^{2}$ add positive news on how to reduce childhood obesity. Better yet, the results lasted over 2 years.

It may not be surprising that more regular opioid use for longer periods would be associated with increased risk of opioid overdoses, but what may be less well understood is that approximately half of opioid overdoses were among intermittent (rather than daily) users in this 3 -year study. ${ }^{3}$ Physicians

Conflict of interest: The authors are editors of the JABFM. should be aware of this high risk when treating patients with opioids.

Do family physicians and their office staff recommend hand washing and avoiding face touching to decrease the risk of colds and infectious diseases? What are their personal hygiene practices while in the office setting? Find out from this interesting practicebased research network observational study. ${ }^{4}$

Two excellent review articles are included in this issue. Cerimele et $\mathrm{al}^{5}$ presents a review of tobacco use treatment in patients with psychiatric illness, which is often perceived as a difficult conundrum but can, as the authors note, be successful. Useful treatment strategies are presented. In the second review, Thomas and Lodhia ${ }^{6}$ consider the evidence for newer therapies for inflammatory bowel disease.

\section{Brief Clinical Reports}

Brief reports are a favorite of our readers, and this issue includes several. Murdoch et $\mathrm{al}^{7}$ report on a patient with an ovarian teratoma, highlighting the potential for associated multisystem manifestations, including migraine headaches. Leiva et $\mathrm{al}^{8}$ found that ovulation predictor kits (testing for luteinizing hormone) have good potential to assist couples seeking to use fertility awareness methods. Llor et $\mathrm{al}^{9}$ looked at whether C-reactive protein testing was useful to assist with the diagnosis of group A streptococcus pharyngitis-it was not. 


\section{Implementing Patient-Centered Medical Homes}

Medication reconciliation is now required for "meaningful use" of electronic health records and is part of the standard of care in patient-centered medical homes. Medication reconciliation can identify patient confusion or nonadherence, pharmacy errors, and physician mistakes when writing prescriptions. The challenge remains how to best reconcile medications in a cost-effective fashion. Wolff et $\mathrm{al}^{10}$ investigated 2 different methods in a randomized trial. The good news: something works! The bad news: more effort works better.

We value the types of activities conducted in patient-centered medical homes, and those practices that adhere to these values have better quality outcomes. ${ }^{11}$ However, meeting the rigid regulatory guidelines set forth by the National Committee for Quality Assurance is not the same as doing many appropriate patient-centered activities. Hahn et $\mathrm{al}^{12}$ provide interesting information on practices that are innovative but not necessarily certified by the National Committee for Quality Assurance.

\section{Mental and Behavioral Health Care Assessment in (and with) Family Medicine}

Rodriguez et $\mathrm{a}^{13}$ looked at the real-world implementation of conducting both health behavior and mental health screening assessments in primary care practices. The report notes the most common issues reported by patients and provides many helpful details. Physicians liked the assessments, discussed the results with their patients half of the time, but feared whether they had the resources to meet patients' needs, raising the issue of the advisability of screening without the ability to provide appropriate follow-up. ${ }^{14}$ In another report, Miller et $\mathrm{al}^{15}$ found that rural areas are less likely to have family physicians and behavioral health providers located in close proximity. Given that colocation should help providers interact regarding the care of individual patients, integrated care is likely more difficult in rural areas. Yet Burfeind et $\mathrm{al}^{16}$ reported differing opinions on integrating mental health and primary care services by the respective providers.

\section{Recertification}

Do rural physicians perform better or worse on the American Board of Family Medicine recertification exams? What is your guess? Schulte et $\mathrm{al}^{17}$ provide the answers. Personally, I (MAB) think that the breadth of practice that often characterizes family practices in rural America should help physicians be more up to date than some of the more restricted types of practice of some family physicians in urban America. Similarly, physicians with partners could do better because they can share clinical questions and newly found information.

How well do groups work together on recertification modules? Elward et a ${ }^{18}$ report on improvements in asthma care and guideline adherence through a group self-assessment module. We already know that teams working together during school at all levels-from elementary school through medical school-help individuals learn and improve, so it should not be a surprise that learning collaboratives can help family physicians improve patient care as well.

\section{The Annual Hit Parade}

This issue also includes our annual "hit parade" of the most-read articles and content usage. We are proud to report that content activity was up 53\% in 2013 compared with content usage requests during 2012. ${ }^{19}$

\section{References}

1. Espinoza A, Malone K, Balyakina E, Fulda KG, Cardarelli R. Incidental computer tomography radiologic findings through research participation in the North Texas Healthy Heart Study. J Am Board Fam Med 2014;27:314-20.

2. Endevelt R, Elkayam O, Cohen R, et al. An intensive family intervention clinic for reducing childhood obesity. J Am Board Fam Med 2014;27:321-8.

3. Paulozzi LJ, Zhang K, Jones CM, Mack KA. Risk of adverse health outcomes with increasing duration and regularity of opioid therapy. J Am Board Fam Med 2014;27:329-38.

4. Elder NC, Sawyer W, Pallerla H, Khaja S, Blacker $M$. Hand hygiene and face touching in family medicine offices: a Cincinnati Area Research and Improvement Group (CARInG) Network study. J Am Board Fam Med 2014;27:339-46.

5. Cerimele JM, Halperin AC, Saxon AJ. Tobacco use treatment in primary care patients with psychiatric illness. J Am Board Fam Med 2014;27:399-410.

6. Thomas A, Lodhia N. Advanced therapy for inflammatory bowel disease: a guide for the primary care physician. J Am Board Fam Med 2014;27:411-20.

7. Murdoch W, Sadoski J, Rosin FC. Multisystem manifestations of benign ovarian teratomas. J Am Board Fam Med 2014;27:421-3.

8. Leiva R, Burhan U, Kyrillos E, et al. Use of ovulation predictor kits as adjuncts when using fertility 
awareness methods (FAMs): a pilot study. J Am Board Fam Med 2014;27:427-9.

9. Calviño O, Llor C, Gómez F, González E, Sarvisé C, Hernández S. Association between c-reactive protein rapid test and group A streptococcus infection in acute pharyngitis. J Am Board Fam Med 2014;27: 424-6.

10. Wolff C, Nowacki AS, Yeh JY, Hickner J. A randomized controlled trial of two interventions to improve medication reconciliation. J Am Board Fam Med 2014;27:347-55.

11. Pandhi N, DeVoe JE, Schumacher JR, et al. Preventive service gains from first contact access in the primary care home. J Am Board Fam Med 2011;24:351-9.

12. Hahn KA, Gonzalez MM, Etz RS, Crabtree BF. National Committee for Quality Assurance (NCQA) patient-centered medical home $(\mathrm{PCMH})$ recognition is suboptimal even among innovative primary care practices. J Am Board Fam Med 2014;27:312-3.

13. Rodriguez HP, Glenn BA, Olmos T, et al. Realworld implementation and outcomes of health behavior and mental health assessment. J Am Board Fam Med 2014;27:356-66.

14. U.S. Preventive Services Task Force. Recommendations for adults. Available from: http://www.uspre- ventiveservicestaskforce.org/adultrec.htm. Accessed 4 March 2014.

15. Miller BF, Petterson S, Brown-Levey SM, PayneMurphy JC, Moore M, Bazemore A. Primary care, behavioral health, provider colocation, and rurality. J Am Board Fam Med 2014;27:367-74.

16. Burfeind G, Seymour D, Sillau SH, Zittleman L, Westfall JM. Provider perspectives on integrating primary and behavioral health: a report from the High Plains Research Network. J Am Board Fam Med 2014;27:375-82.

17. Schulte BM, Mannino DM, Royal KD, Brown SL, Peterson LE, Puffer JC. Community size and organization of practice predict family physician recertification success. J Am Board Fam Med 2014; 27:383-90

18. Elward K, Blackburn B, Peterson LE, Greenawald $\mathrm{M}$, Hagen MD. Improving quality of care and guideline adherence for asthma through a group selfassessment module. J Am Board Fam Med 2014;27: 391-8.

19. Lupo P, Neale AV, Bowman MA. Content usage and the most frequently read articles by issue in 2013 . J Am Board Fam Med 2014;27:306-8. 